\title{
Keanekaragaman jenis vegetasi strata semak di Kawasan Gunung Api Purba Mujil Girimulyo Kabupaten Kulon Progo sebagai sumber belajar biologi berbasis kearifan lokal
}

\author{
Trikinasih Handayani ${ }^{1 *}$, Dwi Noviana ${ }^{2}$, Hendro Kusumo Eko Prasetyo Moro ${ }^{3}$ \\ Pendidikan Biologi, Fakultas Keguruan dan Ilmu Pendidikan, Universitas Ahmad Dahlan \\ Jl. Jendral Ahmad Yani (Ringroad Selatan) Tamanan, Banguntapan, Bantul \\ Daerah Istimewa Yogyakarta 55191 \\ ${ }^{1}$ trikinasihhandayani@gmail.com *; ${ }^{2}$ dwinoviana888@gmail.com; ${ }^{3}$ morosmart@yahoo.com \\ *korespondensi penulis
}

\begin{abstract}
Abstrak
Penelitian ini bertujuan untuk 1) Mengetahui jenis-jenis vegetasi strata semak di Kawasan Gunung Api Purba Mujil Kulon Progo yang mempunyai INP (Indeks Nilai Penting) tertinggi dan terendah. 2) Mengetahui keanekaragaman jenis vegetasi strata semak di Kawasan Gunung Api Purba Mujil Kulon Progo. 3) Mengetahui keterkaitan kondisi lingkungan abiotik yang terukur meliputi suhu udara, suhu tanah, kelembaban udara, kelembaban tanah, $\mathrm{pH}$ tanah dan intensitas cahaya terhadap pola pengelompokkan stand vegetasi strata semak di Kawasan Gunung Api Purba Mujil Girimulyo Kulon Progo. 4) Menganalisis hasil penelitian tentang keanekaragaman jenis vegetasi strata semak di Kawasan Gunung Api Purba Mujil Kulon Progo sebagai sumber belajar biologi SMA Kelas X materi keanekaragaman hayati.

Pengambilan sampel dalam penelitian ini menggunakan metode Point Centered Quarter. Untuk mengetahui tingkat keanekaragaman digunakan rumus Indeks Keanekaragaman Shanon-Wienner dan untuk mengetahui keterkaitan kondisi lingkungan abiotik yang terukur terhadap pola pengelompokan stand digunakan analisis cluster. Hasil penelitian dikaji potensinya sebagai sumber belajar biologi ditinjau dari kejelasan potensi ketersediaan objek dan permasalahan yang diangkat, kesesuaian dengan tujuan pembelajaran, kejelasan sasaran materi dan peruntukannya, kejelasan informasi yang akan di ungkap, kejelasan pedoman eksplorasi, kejelasan perolehan yang akan dicapai, ketersediaan sumber setempat, dana, tenaga dan fasilitas, keluwesan, kepraktisan dan ketahanan sumber belajar serta keefektifan biaya.

Hasil penelitian menunjukkan bahwa ditemukan 13 jenis vegetasi strata semak di seluruh area kajian dengan INP tertinggi adalah Cromolaena odorata $(96,77 \%)$ dan INP terendah adalah Salacca zalacca $(0,95 \%)$. Indeks keanekaragaman $\left(\mathrm{H}^{\prime}\right)$ jenis vegetasi strata semak tergolong rendah berkisar antara $0,40-0,80$. Kondisi lingkungan abiotik yang berkaitan dengan pola pengelompokan stand jenis vegetasi strata semak adalah kelembaban tanah, $\mathrm{pH}$ tanah dan intensitas cahaya. Melalui metode pengkajian, hasil penelitian ini memenuhi kriteria sebagai sumber belajar Biologi SMA kelas X pada materi pembelajaran keanekaragaman hayati.
\end{abstract}

Kata kunci: keanekaragaman hayati, vegetasi strata semak, sumber belajar

\begin{abstract}
This research is aimed at: 1) knowing the species of bushes stratum vegetation in Ancient volcano Mujil area, Kulon Progo district which has high and low index value important, 2) knowing the diversity of bushes
\end{abstract}


stratum vegetation spesies in Ancient volcano Mujil area, Kulon Progo District, 3) knowing the relation of abiotic environmental condition which measured by air temperature, soil temperature, air humidity, soil humidity, soil $\mathrm{pH}$ and Light Intensity toward the grouping pattern of bushes stratum vegetation stand in Ancient volcano Mujil area, Kulon Progo District, 4) Analyzing the research result about diversity of bushes stratum vegetation spesies in Ancient volcano Mujil area, Kulon Progo District as grade X biology learning material on biodiversity.

Sampling in this study using the Point Centered Quarter methode to determine the level of diversity used the Shanon-Wienner diversity index formula and to determine the interrelationship of measured abiotic enviromental conditions to the stand grouping patterns used claster analysis. The result of this research assessed its potential as learning resource in terms of potential clarity, availability of objects and issue raised, Conformity with learning objectives, clear objectives, the clarity of exploration guidelines, clear information, the clarity of expected gain, Availability of resources, Funds, power and facilities, Flexibility, practicality and resilience of learning resources and Cost effectiveness.

The result was showing that 13 bushes stratum vegetation spesies in all the area with the high index value important is Cromolaena odorata $(96,77 \%)$ and low index value important is Salacca zalacca $(0,95 \%)$. The diversity index of vegetation strata of bushes was classified as low ranging between 0,40-0,80. Abiotic environmental condition that related to the grouping pattern of bushes stratum vegetation stands are soil humidity, soil $\mathrm{pH}$ and light intensity. Through reviewing process method, the result of this research fulfill the criteria of learning resource as grade $\mathrm{X}$ biology learning resources in the material of ecosystem level learning biodiversity.

Keywords: vegetation diversity, bushes stratum, learning resource

\section{PENDAHULUAN}

Menurut kurikulum 2013, peserta didik dituntut untuk lebih aktif dalam proses pembelajaran, sehingga seorang guru harus bisa memanfaatkan berbagai sumber belajar. Sumber belajar biologi dalam proses pembelajaran biologi dapat diperoleh di sekolah atau di luar sekolah (Suhardi, 2012). Pemanfaatan lingkungan diperlukan dalam proses pembelajaran biologi yang bersifat kontekstual agar mendapatkan pengalaman belajar yang lebih bermakna. Salah satu lingkungan yang diharapkan dapat dijadikan sebagai sumber belajar biologi adalah Gunung Api Purba Mujil yang berada di Kulon Progo Yogyakarta.

Gunung Api Purba Mujil terletak di Dusun Nglengkeh, Kelurahan Pendoworejo, Kecamatan Girimulyo Kabupaten Kulon Progo Daerah Istimewa Yogyakarta Gunung Api Purba Mujil merupakan salah satu sistem Gunung Api Purba, yang terlepas dari sistem Gunung Api di pegunungan Kulon Progo (Hartono \& Pambudi 2016). Kawasan Gunung Mujil banyak ditumbuhi oleh jenis-jenis vegetasi, salah satu jenis vegetasinya adalah strata semak. 
Menurut Michael (Handayani, 2018) semak merupakan tumbuhan yang tidak seberapa besar, batang berkayu, bercabang-cabang dekat pemukaan tanah dan tingginya kurang dari 8 meter Menurut Heyne (Fredinan, 2011) peran semak untuk mencegah terjadinya erosi dilereng pegunungan. Keanekaragaman jenis vegetasi strata semak Gunung Api Purba Mujil memiliki potensi untuk dapat dijadikan sumber belajar biologi kelas $\mathrm{X}$ materi keanekaragaman hayati, oleh karena itu penelitian ini perlu dilakukan.

\section{METODE}

Jenis penelitian yang digunakan adalah penelitian eksploratif. Teknik pengumpulan data dengan menggunakan metode Plotless yaitu Point Centered Quarter. Untuk mengetahui keanekaragaman jenis vegetasi strata semak digunakan Indeks Shannon-wienner. Untuk mengetahui keterkaitan kondisi lingkungan abiotik yang terukur dengan pola pengelompokkan stand vegetasi strata semak digunakan analisis cluster.

\section{HASIL DAN PEMBAHASAN}

\section{A. Indeks Nilai Penting Vegetasi Strata Semak di Seluruh Area Kajian}

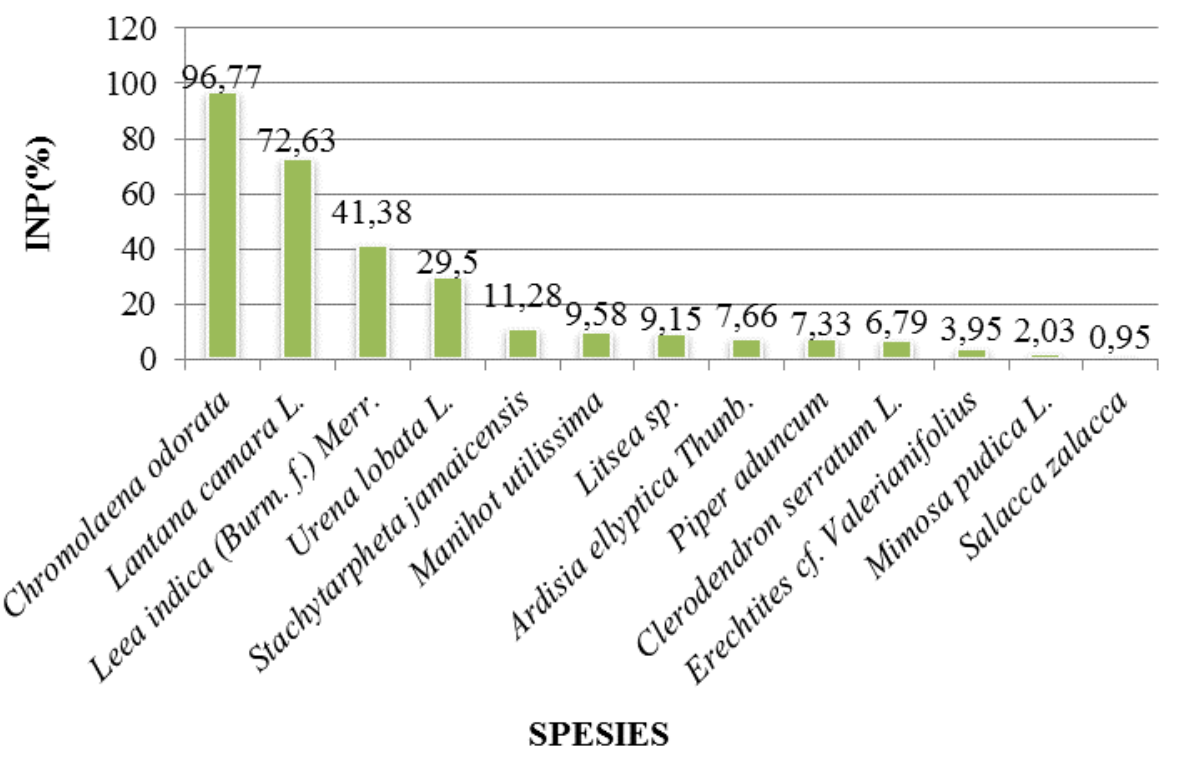

Gambar 1. Grafik Batang Rerata INP (Indeks Nilai Penting) Jenis Vegetasi Strata Semak diseluruh Area Kajian

Berdasarkan hasil penelitian menunjukkan bahwa terdapat 13 jenis vegetasi strata semak pada seluruh area kajian. Dapat dilihat dari gambar 1. Vegetasi strata semak yang memiliki rerata INP terbesar yaitu Chromolaena odorata (96,77\%). Jenis vegetasi yang memiliki rerata 
INP terendah yaitu Salacca zalacca (0,95\%). Besarnya INP menunjukkan bahwa Chromolaena odorata memiliki peranan penting dalam komunitas di Kawasan Gunung Api Purba Mujil Kulon Progo. Selain itu, karena kondisi lingkungan abiotik yang sesuai bagi pertumbuhan jenis tersebut. Chromolaena odorata bersifat kosmopolit atau mudah tumbuh dimana saja dan tidak memerlukan syarat unsur hara yang tinggi, sehingga tumbuhan ini menduduki habitat yang cukup luas . (Thamrin, 2013).

Jenis vegetasi strata semak dengan nilai INP terendah adalah Salacca zalacca $(0,95 \%)$ yang ditemukan diarea kajian A. Rendahnya Indeks Nilai Penting (INP) Salcca zalacca tersebut menunjukkan peranan yang rendah di Kawasan Gunung Api Purba Mujil Girimulyo Kabupaten kulon Progo. Menurut Suskendriyati (2000) Salacca zalacca dapat tumbuh secara optimal pada suhu $20-30^{\circ} \mathrm{C}$. Tanaman salak tidak menyukai sinar matahari secara langsung, tetapi hanya membutuhkan sinar matahari $50-70 \%$, sehingga tanaman salak memerlukan pohon penaung. Tanaman salak menyukai tanah yang subur, gembur dan lembab dengan derajat keasaman tanah $(\mathrm{pH})$ yang cocok adalah 4,5-7,5 dan dapat tumbuh pada ketinggian tempat 100-500 mdpl. Tanaman salak yang tumbuh tanpa naungan daunnya akan terbakar, pertumbuhannya sangat lambat, dan produksi buahnya sedikit. Faktor abiotik terukur pada area kajian A memiliki rerata suhu udara $28,3^{\circ} \mathrm{C}$, kelembaban udara $66,7 \%$ kelembaban tanah $68,7 \%, \mathrm{pH}$ tanah 6,4 dan Intensitas cahaya 795,8 lux. Area kajian B memiliki rerata abiotik antara lain suhu udara $33^{\circ} \mathrm{C}$ suhu tanah $28,9^{\circ} \mathrm{C}$, kelembaban udara $60 \%$ kelembaban tanah 59,1\%, pH tanah 6,21 dan Intensitas cahaya 674,2 lux. Area kajian C memiliki rerata abiotik antara lain suhu udara $29,7^{\circ} \mathrm{C}$, suhu tanah $28,1^{\circ} \mathrm{C}$, kelembaban udara $71,1 \%$, kelembaban tanah 61\%, pH tanah 6,28 dan Intensitas Cahaya 667,7 lux. Hal ini dapat diketahui bahwa suhu udara di Area Kajian B serata kelembaban udara di Area kajian C yang mengakibatkan tidak sesuainya dengan syarat tumbuh optimal pertumbuhan Salacca zalacca sehingga mengakibatkan tidak ditemukannya pertumbuhan Salacca zalacca di area kajian tersebut, dan hanya ditemukan di area kajian A.

Vegetasi strata semak yang umum ditemukan di semua area kajian adalah Urena lobata L. dengan rerata INP sebesar 29,5\% dan Leea indica (Bur. F) Merr. dengan rerata INP sebesar 41,38\%. Menurut Azizah (2017) pulutan (Urena lobata L) merupakan jenis dari suku Malvaceae yang mempunyai sistem perakaran tunggang dan tipe buah yang memiliki kait. Tipe buah yang memiliki kait mempunyai karakter yang mudah melekat sehingga memperluas jangkauan persebarannya. Menurut Oktavianto (2017) kondisi lingkungan abiotik yang optimum untuk tumbuhnya tanaman Urena lobata L. yaitu suhu tanah $25,33^{\circ} \mathrm{C}$, 
intensitas cahaya sebesar 156,67 lux, kelembaban udara sebesar 75,50\%, suhu udara sebesar $32,33^{\circ} \mathrm{C}$ dan $\mathrm{pH}$ tanah sebesar 6,57. Faktor abiotik terukur pada area kajian A memiliki rerata suhu udara $28,3^{\circ} \mathrm{C}$, kelembaban udara $66,7 \%$ kelembaban tanah $68,7 \%$, pH tanah 6,4 dan Intensitas cahaya 795,8 lux. Area kajian B memiliki rerata abiotik antara lain suhu udara $33^{\circ} \mathrm{C}$ suhu tanah $28,9^{\circ} \mathrm{C}$, kelembaban udara $60 \%$ kelembaban tanah $59,1 \%$, pH tanah 6,21 dan Intensitas cahaya 674,2 lux. Area kajian C memiliki rerata abiotik antara lain suhu udara $29,7^{\circ} \mathrm{C}$, suhu tanah $28,1^{\circ} \mathrm{C}$, kelembaban udara $71,1 \%$, kelembaban tanah $61 \%$, pH tanah 6,28 dan Intensitas Cahaya 667,7 lux. Hasil tersebut dapat diketahui bahwa intensitas cahaya tidak sesuai dengan pertumbuhan Urena lobata L. karena rerata intensitas cahaya di seluruh area kajian tersebut terlalu tinggi, sedangkan faktor abiotik yang terukur berupa suhu udara, suhu tanah, kelembaban udara, kelembaban tanah, dan $\mathrm{pH}$ tanah sesuai dengan kondisi umum tumbuhan Urena lobata L. Menurut Tjitrosoepomo (Azizah, 2017) Urena lobata L. merupakan jenis dari suku Malvaceae yang mempunyai sistem perakaran tunggang dan tipe buah yang memiliki kait. Tipe buah yang memiliki kait memiliki karakter yang mudah melekat sehingga memperluas jangkauan persebarannya. Selain itu kondisi lingkungan yang tidak terlalu banyak naungan menjadikan pulutan (Urena lobata L.) mempunyai kelimpahan yang tinggi. Tumbuhan Malvaceae merupakan tumbuhan dikotil yang memiliki bentuk daun terbagi dan bergerigi, dapat tumbuh dalam berbagai jenis $\mathrm{pH}$ dan tekstur tanah, serta dapat tumbuh optimal di bawah sinar matahari penuh (Ningrum dkk., 2016).

Vegetasi strata semak yang umum selanjutnya adalah Leea indica (Burm f.) Merr. memiliki rerata INP sebesar 29,5\%. Nama daerahnya adalah girang atau mali-mali hantu. Semak dengan tinggi mencapai $5 \mathrm{~m}$. Batang tegak, berkayu, bulat, bekas melekatnya daun tampak jelas, dan berwarna hijau. Daun hijau, majemuk, berseling, lonjong, pertulangan menyirip, panjang 8-16 cm, lebar 3-7 cm, dan bertangkai bulat. Bunga berwarna hijau, majemuk, berkelamin dua, berbentuk payung, di ketiak daun, kelopak berbentuk bintang, mahkota berbentuk torong, kepala sari berwarna putih. Jenis ini tersebar dari dataran rendah sampai ketinggian tempat $1.700 \mathrm{~m}$ dpl (Wibisono, 2017). Leea indica (Burm f.) Merr. Termasuk dalam famili Meliaceae, kondisi lingkungan abiotik yang optimum untuk tumbuhnya Leea indica (Burm f.) Merr. yaitu suhu udara berkisar $28^{\circ} \mathrm{C}$ dengan kelembaban $70 \%$ dan $\mathrm{pH}$ netral (Suryanto, 2014). Hasil data didapatkan faktor abiotik terukur pada area kajian A memiliki rerata suhu udara $28,3^{\circ} \mathrm{C}$, kelembaban udara $66,7 \%$ kelembaban tanah $68,7 \%$, pH tanah 6,4 dan intensitas cahaya 795,8 lux. Area kajian B memiliki rerata abiotik antara lain suhu udara $33^{\circ} \mathrm{C}$ suhu tanah $28,9^{\circ} \mathrm{C}$, kelembaban udara $60 \%$ kelembaban tanah 59,1\%, pH tanah 6,21 dan Intensitas cahaya 674,2 lux. Area kajian C memiliki rerata abiotik 
antara lain suhu udara $29,7^{\circ} \mathrm{C}$, suhu tanah $28,1^{\circ} \mathrm{C}$, kelembaban udara $71,1 \%$, kelembaban tanah 61\%, pH tanah 6,28 dan Intensitas Cahaya 667,7 lux. Hasil tersebut dapat diketahui bahwa suhu udara, kelembaban udara, dan $\mathrm{pH}$ tanah sesuai dengan kondisi umum, lebih lanjut (Suryanto, 2014) mengatakan bahwa fenologi di daerah tropika sangat tergantung pada perubahan hidroperiodik sebagai akibat perubahan musim hujan dan kemarau, namun tingginya intensitas curah hujan hingga akhir tahun tidak berpengaruh terhadap proses berbunga dan berbuah tanaman Leea indica (Burm f.) Merr., sehingga tidak heran jika tanaman tersebut mampu tumbuh dengan baik dan dapat ditemui di semua area kajian.

\section{B. Indeks Keanekaragaman (H')}

Keanekaragaman jenis yang terdapat dalam komunitas dapat diketahui dari Indeks Keanekaragaman. Indeks Keanekaragaman jenis digunakan untuk mengetahui pengaruh gangguan terhadap lingkungan atau untuk mengetahui kestabilan dari komunitas tumbuhan pada suatu lokasi (Muwazin, 2013). Indeks keanekaragaman merupakan parameter vegetasi yang sangat berguna untuk membandingkan berbagai komunitas tumbuhan, terutama untuk mempelajari pengaruh gangguan faktor-faktor lingkungan atau abiotik terhadap komunitas atau stabilitas komunitas. Suatu komunitas pada umumnya terdapat berbagai jenis tumbuhan, maka semakin tua atau semakain stabil keadaan suatu komunitas, semakin tinggi keanekaragaman jenis tumbuhannya. Indeks keanekaragaman dapat diperoleh dengan menggunakan rumus Shannon-Wienner (Fachrul, 2012).

Hasil rerata indeks keanekaragaman di area kajian A sebesar 0,64 area kajian B sebesar 0,62 dan area kajian C sebesar 0,61. Indeks keanekaragaman pada keseluruhan area kajian menunjukkan bahwa semua Indeks Keanekaragamannya rendah, hal tersebut sesuai dengan pendapat Fachrul (2012) jika nilai $H^{\prime}<1$ menunjukkan bahwa keanekaragaman suatu spesies tersebut rendah. Rendahnya indeks keanekaragaman ini dikarenakan vegetasi strata semak memiliki kemerataan spesies (jenis) yang rendah. Hal ini ditunjukan dengan adanya rerata nilai frekuensi relatif dari 13 spesies tersebut tergolong rendah $(9,22 \%)$. Hal ini sesuai dengan pernyataan Hardjosuwarno (1990) yang menyatakan bahwa keanekaragaman jenis adalah kekayaan jenis yang dibobot dengan kemerataan jenis. 


\section{Analisis Cluster}

Tabel 1. Analisis Cluster Faktor Lingkungan Abiotik yang terukur dengan pola pengelompokkan stand vegetasi strata semak.

\begin{tabular}{|c|c|c|c|c|c|c|}
\hline & \multicolumn{2}{|c|}{ Cluster } & \multicolumn{2}{|c|}{ Error } & \multirow[t]{2}{*}{$\mathbf{F}$} & \multirow[t]{2}{*}{ Sig. } \\
\hline & $\begin{array}{l}\text { Mean } \\
\text { Square }\end{array}$ & df & $\begin{array}{l}\text { Mean } \\
\text { Square }\end{array}$ & df & & \\
\hline Suhu Udara & 3.392 & 1 & 3.717 & 28 & .913 & .348 \\
\hline Suhu Tanah & .199 & 1 & 1.113 & 28 & .179 & .676 \\
\hline Kelemban Udara & 7.792 & 1 & 36.146 & 28 & .216 & .646 \\
\hline Kelembaban Tanah & 234.388 & 1 & 13.981 & 28 & 16.764 & .000 \\
\hline Ph Tanah & .219 & 1 & .027 & 28 & 8.025 & .008 \\
\hline Intensitas Cahaya & 115645.125 & 1 & 2164.217 & 28 & 53.435 & .000 \\
\hline
\end{tabular}

Dari hasil analisis cluster menunjukkan bahwa faktor abiotik yang tidak berpengaruh terhadap pola pengelompokan stand adalah suhu udara 0,348 suhu tanah 0,676 dan kelembaban udara 0,646 sedangkan faktor abiotik yang berpengaruh terhadap pola pengelompokkan stand adalah kelembaban tanah 0,000, pH tanah 0,008 dan Intensitas cahaya 0,000 .

Hal tersebut dapat dilihat dari nilai sig $>0,05$. Menurut Trihendradi (2011) Jika Sig $>\alpha$ $(0,05)$, maka Ho diterima (Faktor abiotik terukur berpengaruh terhadap pola pengelompokan stand) dan Jika $\operatorname{Sig}<\alpha(0,05)$, maka Ho ditolak (Faktor abiotik terukur tidak berpengaruh terhadap pola pengelompokan stand).

\section{Analisis Potensi Hasil Penelitian Sebagai Sumber Belajar Biologi Sma Kelas X}

Menurut Djohar (Suhardi, 2012) syarat-syarat yang dapat dijadikan sebagai sumber belajar biologi adalah sebagai berikut:

\section{Kejelasan potensi ketersediaan objek dan permasalahan yang diangkat.}

Objek yang diamati dalam penelitian ini yaitu vegetasi strata semak yang terdapat di Kawasan Gunung Api Purba Mujil Girimulyo Kabupaten Kulon Progo, dijadikannya vegetasi strata semak sebagai objek dari penelitian karena mudah diamati dan dikenali (identifikasi) berdasarkan ciri-ciri morfologi yang ada serta sangat mudah untuk ditemui disekitar kita. Permasalahan yang diangkat kaitannya dengan potensi sebagai sumber belajar materi Keanekaragaman Hayati yaitu kurangnya contoh-contoh yang bersifat konstektual yang berbasis pada potensi lokal pada materi keanekaragaman hayati kelas X SMA. 


\section{Kesesuaian dengan tujuan pembelajaran}

Tujuan pembelajaran dari kurikulum dimuat dalam Kompetensi Dasar (KD) 3.2 yaitu Menganalisis berbagai tingkat keanekaragaman hayati (gen, jenis, ekosistem) di Indonesia beserta ancaman dan pelestariannya, yang disesuaikan dengan tujuan yang mengacu pada kurikulum 2013 pada materi keanekaragaman hayati, yaitu:

a. Peserta didik mampu menyebutkan jenis-jenis vegetasi strata semak di Kawasan Gunung Api Purba Mujil Girimulyo Kabupaten Kulon Progo

b. Peserta didik mampu memyebutkan contoh-contoh jenis vegetasi yang memiliki peranan tertinggi dan terendah pada suatu ekosistem.

c. Peserta didik mampu menganalisis konsep keanekaragaman hati khususnya pada tingkat ekosistem

\section{Kejelasan sasaran dan materi peruntukannya}

Sasaran materi (objek) dalam penelitian ini adalah materi Keanekaragaman Hayati kelas X SMA khususnya keanekaragaman pada tingkat ekosistem, sedangkan sasaran peruntukan pada penelitian ini adalah untuk peserta didik SMA kelas X.

\section{Kejelasan informasi yang diungkap}

Berdasarkan penelitian yang telah dilakukan diperoleh kejelasan informasi yang dapat diungkap dari hasil penelitian ini yaitu berupa produk penelitian. Produk penelitian yang diperoleh dari hasil penelitian ini adalah berupa fakta dan konsep. Adapun faktanya berupa hasil penelitian telah ditemukan 13 spesies vegetasi strata semak yang berada di Kawasan Gunung Api Purba Mujil Girimulyo Kabupaten Kulon Progo. Rerata INP tertinggi adalah Chromolaena odorata sebesar 96,77\% jenis vegetasi strata semak yang memiliki INP terendah yaitu Salacca zalacca sebesar 0,95\%. Konsep dari produk penelitian ini adalah keanekaragaman hayati di Kawasan Gunung Mujil Girimulyo Kulon Progo yang merupakan keanekaragaman hayati tingkat ekosistem.

\section{Kejelasan pedoman eksplorasi}

Berdasarkan penelitian yang telah dilakukan diperoleh kejelasan pedoman eksplorasinya dengan cara mengungkap jelas informasi mengenai keanekaragaman

jenis vegetasi strata semak di Kawasan Gunung Api Purba Mujil Girimulyo Kabupaten Kulon Progo dengan langkah-langkah prosedur yang jelas meliputi 
penentuan objek penelitian, alat dan bahan, cara kerja, analisis data serta penarikan kesimpulan. Hasil penelitian dapat digunakan untuk mendukung tercapainya KD 3.2 Menganalisis berbagai tingkat keanekaragaman hayati (gen, jenis, ekosistem) di Indonesia beserta ancaman dan pelestariannya, namun demikian dari hasil penelitian ini tidak bisa untuk mecapai keseluruhan dari KD 3.2 tersebut. Hasil penelitian ini hanya bisa digunakan untuk memberikan contoh-contoh yang kontekstual pada keanekaragaman hayati tingkat ekosistem, dan dalam pencapaiannya tetap mempertimbangkan kemampuan peserta didik dan keterbatasan waktu serta indikator yang diharapkan.

\section{Kejelasan perolehan yang akan di capai}

Berdasarkan hasil penelitian, kejelasan perolehan yang akan dicapai dapat membantu peserta didik dalam mencapai tujuan pembelajaran yang meningkatkan nilai afektif, kognitif dan psikomotorik.

Selain ke-enam syarat sumber belajar biologi menurut Djohar (Suhardi, 2012) terdapat pula persyaratan sumber belajar menurut Dick \& Carey (Supriadi, 2015) yaitu:

\section{Ketersediaan sumber belajar setempat}

Penelitian ini tersedia sumber belajar yang memudahkan peserta didik belajar dalam materi keanekaragaman hayati khususnya tingkat ekosistem yaitu di Kawasan Gunung Api Purba Mujil Girimulyo Kabupaten Kulon Progo, karena kawasan tersebut memiliki jenis-jenis vegetasi strata semak yang dapat dijadikan sebagai sumber belajar.

\section{Dana, tenaga dan fasilitas}

Dana dan tenaga yang dibutuhkan untuk menggunakan sumber belajar di Kawasan Gunung Mujil Kulon Progo dalam materi Keanekaragaman Hayati relatif sedikit, hal ini dikarenakan jarak lokasi Gunung Api Purba Mujil Girimulyo Kulon Progo dengan lingkungan pendidikan (sekolah) relatif dekat, sehingga dapat menghemat dana, transportasi dan tenaga. Fasilitas yang digunakan untuk menunjang pembelajaran tergolong sederhana diantaranya adalah thermometer, hygrometer.

3. Faktor keluwesan, kepraktisan, dan ketahanan sumber belajar Kawasan Gunung Api Purba Mujil Girimulyo Kulon Progo tidak membutuhkan proses dan tahapan yang rumit untuk dijadikan sebagai sumber belajar, karena mudah untuk melakukan pengamatan. Kawasan yang masih terjaga kelestariannya menjadikan kawasan Gunung Mujil dapat digunakan sebagai sumber belajar dalam jangka waktu yang relatif lama. 


\section{Efektifitas biaya}

Pembiayaan yang diperlukan untuk menjadikan Gunung Api Purba Mujil Mujil Girimulyo Kabupaten Kulon Progo sebagai sumber belajar tergolong murah dan efektif. Hal ini dikarenakan lokasi Gunung Api Purba Mujil Girimulyo Kabupaten Kulon Progo yang mudah di akses serta pemanfaatannya sebagai sumber belajar tidak memerlukan proses yang rumit, sehingga menghemat pembiayaan yang diperlukan.

\section{SIMPULAN}

Berdasarkan hasil penelitian dapat disimpulkan sebagai berikut :

1. Jenis vegetasi strata semak yang ditemukan dikawasan Gunung Api Purba Mujil Girimulyo Kabupaten Kulon Progo didapatkan sebanyak 13 jenis. Jenis yang memiliki Indeks Nilai Penting (INP) tertinggi adalah Chromolaena odorata sebesar 96,77\% dan jenis tumbuhan strata semak dari seluruh area kajian yang mempunyai rerata Indeks Nilai Penting (INP) terendah adalah Salacca zalacca sebesar 0,95\%.

2. Keanekaragaman jenis vegetasi strata semak di Kawasan Gunung Api Purba Mujil Girimulyo Kabupaten Kulon Progo tergolong rendah dengan kisaran indeks keanekaragaman (H') 0,40-0,80.

3. Berdasarkan hasil uji analisis cluster didapatkan bahwa pola pengelompokkan stand dibagi menjadi dua, yaitu Cluster 1 dan Cluster 2. Faktor lingkungan abiotik yang berkaitan dengan pola pengelompokan stand vegetasi strata semak adalah kelembaban tanah, pH tanah dan Intensitas cahaya, sedangkan suhu udara, suhu tanah dan kelembaban udara tidak berkaitan.

4. Berdasarkan metode pengkajian, proses dan hasil penelitian keanekaragaman jenis vegetasi strata semak dikawasan Gunung Api Purba Mujil Girimulyo Kabupaten Kulon Progo berpotensi sebagai sumber belajar biologi SMA kelas X pada materi keanekaragaman hayati.

\section{REFERENSI}

Azizah, Putri, Nur. 2017. Analisis Vegetasi di Kawasan Sekitar Mata Air Ngembel Kecamatan Pajangan Kabupaten Bantul. Jurnal Riset Daerah. Vol. XVI No 1.

Fachrul, Melati, Ferianita. 2012. Metode Sampling Bioekologi. Jakarta: Bumi Aksara. 
Fredinan, Kumolo, B., dan Sri Utami. 2011. Jenis-Jenis Tumbuhan Anggota Famili Asteraceae di Wana Wisata Nglimut Gonoharjo Kabupaten Kendal Jawa Tengah. BIOMA. Juni 2011 ISSN : 1410-8801 Vol. 13, No. 1.

Handayani, Trikinasih dan Mega Melia. 2018. Keanekaragaman Jenis Vegetasi Strata Semak di Kawasan Gunung Tidar Kota Magelang sebagai Sumber Belajar Biologi. SENDIKA: Seminar Nasional Pendidikan FKIP UAD. ISSN: 2598-6481.

Hardjosuwarno, Sunarto. 1990. Ekologi Tumbuhan Jilid 2. Yogyakarta: Fakultas Biologi Universitas Gajah Mada.

Hartono dan Pambudi. 2016. Indikasi Keberadaan Mineralisasi di Sekitar Gunung Mujil Kecamatan Girimulyo Kabupaten Kulon Progo Yogyakarta.. Prosiding Seminar Nasional XI"Rekayasa Teknologi Industri dan Informasi Sekolah Tinggi Teknologi Nasional Yogyakarta".

Muwazin dan Atok Subiakto. 2013. Keanekaragaman dan Komposisi Jenis Permudaan Alam Hutan Rawa Gambut Bekas Tebangan di Riau. Forest Rehabilitation Journal. Vol. 1 No. 1, September 2013: 59-73.

Oktavianto, Elif dan Trikinasih Handayani. 2017. Analisis Vegetasi Strata Semak di Zona Inti Gumuk Pasir Desa Parangtritis Kecamatan Kretek Kabupaten Bantul Yogyakarta sebagai Sumber Belajar Biologi SMA Kelas X. Jurnal Riset Daerah (Edisi Khusus).

Ningrum, K.R., Ni Kadek Surtantari, Fawzia La Rizmma Anindita. 2016. Studi Anatomi Daun dari Tiga Anggota Suku Malvaceae di Kawasan Waduk Jatiluhur. Proceeding Biology Education Conference (ISSN: 2528-5742), Vol 13(1) 2016: 611-618.

Suhardi. 2012. Pengembangan Sumber Belajar Biologi. Yogyakarta: Jurdik Biologi FMIPA UNY.

Supriadi. 2015. Pemanfaatan Sumber Belajar Dalam Proses Pembelajaran. Lantanida Journal. Vol. 3 No. 2.

Suryanto, Heri. 2014. Fenologi beberapa Jenis Pakan Kupu-Kupu Di Taman Nasional Bantimurung Bulusaraung. Info Teknis EBONI. Vol. 11 No. 2, Desember 2014 : 117 127.

Suskendriyati, H., Artawijayati, Nurhidayah, Dewi Cahyaningrum. 2000. Studi Morfologi dan Hubungan Kekerabatan Varietas Salak Pondoh(Salacca zalacca (Gaert.) Voss.) di Dataran Tinggi Sleman. BIODIVERSITAS. Vol. 1, No. 2, Juli 2000, hal. 59-64. ISSN: 1412-033X.

Thamrin, S., Aisikin, Wililis. 2013. Tumbuhan Kirinyu Chromolaena odorata (L) (Asteraceae:Asterales) sebagai Insektisida Nabati untuk Mengendalikan Ulat Grapyak. Spodoptera litura. Jurnal Litbang Pertanian. Vol. 32 No. 3 September 2013: 112-121.

Trihendradi, C. 2011. Langkah-langkah mudah melakukan analisis statistik menggunakan SPSS 19. Yogyakarta: Andi.

Wibisono, Y., dan Azham Z. 2017. Inventarisasi Jenis Tumbuhan Yang Berkhasiatsebagai Obat Pada Plot Konservasi Tumbuhan Obat Di KHDTK Samboja Kecamatan Samboja Kabupatenkutai Kartanegara. Jurnal AGRIFOR. Volume XVI Nomor 1. ISSNP: 1412-6885, ISSN O: 2503-4960. 


\section{LAMPIRAN}

Lampiran 1. Peta Lokasi Gunung Api Purba Mujil Girimulyo Kulon Progo.

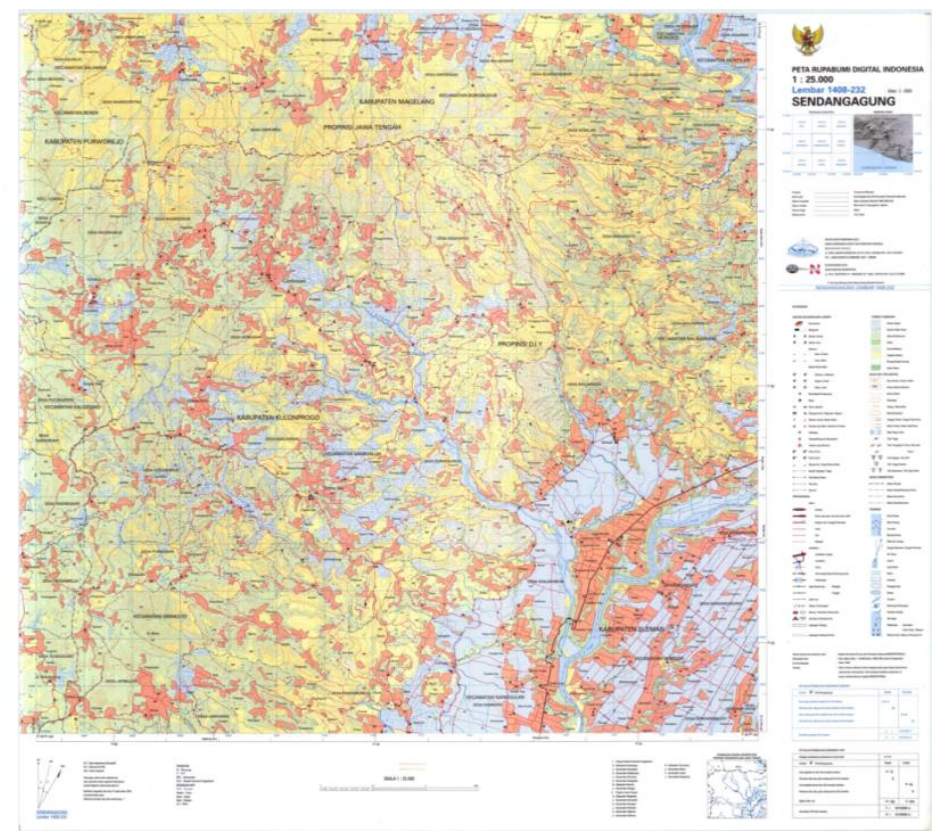

Gambar 1. Peta Rupa bumi Digital Indonesia Sendangagung

(Sumber : Badan Geospasial, 2019).

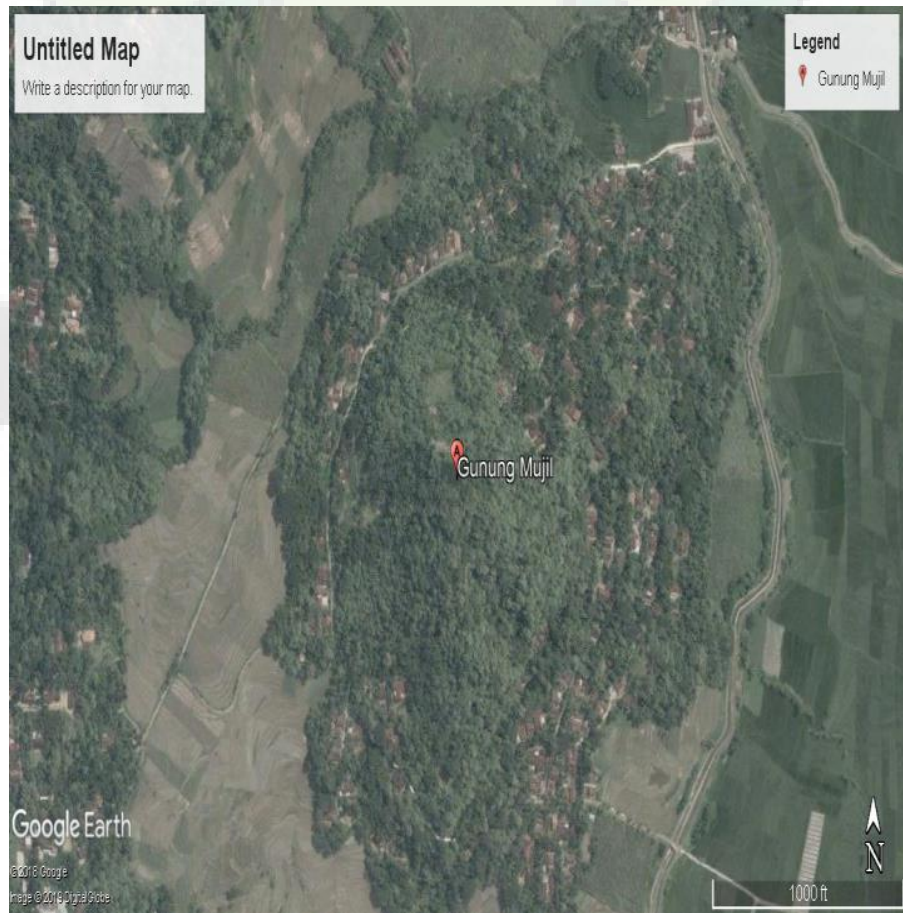

Gambar 2. Peta Lokasi Penelitian di Gunung Mujil Girimulyo

(Sumber : Google Earth, 2019). 